\title{
Research on the Nature and Application of Lifelong Imprisonment
}

\author{
Chen Chao \\ College of political Science and Law, Northeast normal University, Jilin, China
}

Keywords: lifelong imprisonment; nature; application

Abstract: As a highlight of the Amendment to the Criminal Law of the People's Republic of China (9), "Lifelong imprisonment" has aroused heated discussion among scholars since its introduction. In this regard, this paper explores the nature and application of lifelong imprisonment, and reflections on the System of Lifelong Imprisonment.

Lifelong imprisonment, as a highlight of the Amendment to the Criminal Law of the People's Republic of China (9), has aroused heated discussion among scholars since its introduction. However, whether the debate on its nature or the discussion on its specific application are mostly confined to the scope of pure criminal law theory, which is not only different and difficult to conclude up to now, but also inevitably abstract and empty. Therefore, it is necessary to reconsider the system of lifelong imprisonment in the light of specific judicial practice in order to clarify its basic nature and application.

\section{Core Concept}

Lifelong imprisonment refers to a criminal who has been sentenced to death with a reprieve for serious corruption or bribery. After his sentence has been commuted to lifelong imprisonment according to law at the end of the execution period, he shall remain in prison for life and shall not be commuted or paroled. From the analysis of word structure, the term "lifelong imprisonment" is a combination of "lifelong imprisonment" and "imprisonment". The so-called "lifelong", as its name implies, refers to the physical orientation, has the meaning of lifelong. The so-called imprisonment refers to imprisonment and deprivation of liberty. Obviously, the meaning of lifelong imprisonment refers to the penalty measures of imprisoning prisoners indefinitely and depriving them of their personal freedom.

Article 383 of the Criminal Law stipulates the system of lifelong imprisonment. Analyzing the sentence structure of "lifelong imprisonment, no commutation or parole", we can see that "lifelong imprisonment" and "no commutation or parole" point to the same concept. "No commutation or parole" plays an important role in emphasizing and explaining the term "lifelong imprisonment", so "no commutation or parole" is the synonym of "lifelong imprisonment". Therefore, the legal nature of "lifelong imprisonment" is the legal nature of "no commutation or parole". 


\section{The nature of lifelong imprisonment}

The Amendment to the Criminal Law (IX) adopted by our country on November 1, 2015 creatively incorporates the system of lifelong imprisonment into it. However, as a new thing appearing in the provisions of the criminal law, the system of lifelong imprisonment has been discussed only in the third draft of the draft amendment to the criminal law, and only through it. One discussion passed. However, according to the regulation of lifelong imprisonment abroad and ancient Chinese law, lifelong imprisonment does not appear in Chinese law, and it appears in the form of lifelong imprisonment. This is a great challenge for Chinese criminal law scholars and their law applicants and enforcers. Since the lifelong imprisonment system was written into the criminal law, various scholars have discussed the legal nature of the lifelong imprisonment system extensively and deeply, as shown in the following figure:

1.Lifelong imprisonment is an independent form of punishment

2.Lifelong imprisonment is a specific measure of penalty enforcement

3. Lifelong imprisonment is an alternative to death penalty

Figure1 The nature of lifelong imprisonment

This chapter will clarify the position of lifelong imprisonment system in China's penal system through the discussion of the above three issues, in order to better understand the lifelong imprisonment system, and lay a good foundation for the use of lifelong imprisonment system.

\subsection{Lifelong imprisonment is an independent form of punishment}

Among the opinions of many scholars who discuss the nature of lifelong imprisonment in China, one point of view was first put forward by many scholars, that is, lifelong imprisonment should be regulated independently as a kind of punishment in China's legal system and applied to China's judicial practice.

The reason for this statement is that lifelong imprisonment has been discussed by scholars as an imported product, but before it was introduced into China, in many foreign countries where lifelong imprisonment is applicable, although lifelong imprisonment has been given different names and interpreted differently, lifelong imprisonment is still regarded as an independent one. The types of penalties are regulated and applied. While discussing, the experts and scholars who introduced this viewpoint unconsciously applied the general viewpoints of foreign scholars on lifelong imprisonment, believing that they should also have the same understanding and application. At the same time, some scholars believe that if we do not understand lifelong imprisonment, it will lead to repeated evaluation of lifelong imprisonment without commutation or parole, and there will be legislative errors. Since there are errors in the evaluation of legislation, we can only make a relatively reasonable interpretation of this far-fetched.

However, the above-mentioned viewpoints ignore the background of the times and legislation that Chinese law stipulates it in China's Criminal Code. The reason why China has clearly stipulated lifelong imprisonment in its legal provisions is to form a deterrent effect on the rampant corruption and bribery in China's present society in order to improve China's political environment and alleviate social contradictions so as to achieve better leadership of the Communist Party of China. Therefore, legislators do not intend to add an independent type of punishment to China's penal system, so this statement is out of touch with the Chinese society, and it is a kind of unreasonable 
understanding and interpretation.

\subsection{Lifelong imprisonment is a specific measure of penalty enforcement}

Through the provisions of the Amendment (9) to the Criminal Law, we can see that the position of lifelong imprisonment is to regulate the crime of corruption and bribery, which is different from the applicable rules applicable to all charges. Therefore, lifelong imprisonment is only a consideration of sentencing the crime of corruption and bribery. It is a specific sentencing rule, that is, lifelong imprisonment is a specific penalty measure.

\subsection{Lifelong imprisonment is an alternative to death penalty}

With the development of society and economy, the influence of free thought on people is deepening, and all the people in every country, every industry and every profession are in possession of it.They are calling for the protection of human rights. As far as China's legal and judicial environment is concerned, although the application of death penalty conforms to China's history, the application of death penalty has been criticized by many countries and is not conducive to the protection of human rights. Sooner or later, China will abolish the death penalty, so there is a lifelong imprisonment system which is more severe and deterrent than lifelong imprisonment. It is accepted by most experts and scholars.

\section{Application of lifelong imprisonment}

\subsection{Retrospective effect of lifelong imprisonment}

\subsubsection{Judgment of activity}

According to the relevant provisions of the Interpretation of Time Effectiveness, we should interpret and understand the activity of lifelong imprisonment in the application process as follows: when we evaluate the offender's behavior, we should only evaluate the offender's behavior according to the old law before the promulgation and application of the Amendment to the Criminal Law (9). If the application of the death penalty suspension of execution can adapt to the crime, responsibility and punishment and reflect fairness and justice, it should be evaluated and applied according to the old law before the Criminal Law Amendment (9). If the old law can not achieve fairness and justice, can not reasonably and legally evaluate the behaviorist, and can not be properly punished. Its crime should apply the applicable rules of the new law on lifelong imprisonment in order to achieve fairness and justice.

\subsubsection{Identification of the time point of sentence of lifelong imprisonment}

According to the analysis of the applicable conditions of lifelong imprisonment in the Amendment to the Criminal Law (9), we still have a very important problem to discuss when to apply lifelong imprisonment, that is, when to pronounce the application of lifelong imprisonment. The Interpretation of Time Effectiveness stipulates that the death penalty may be suspended for two years according to the specific circumstances of the crime, and that lifelong imprisonment shall be applied without commutation or parole.

It can be seen from this that for the application of lifelong imprisonment, the judge must declare the application of lifelong imprisonment to the offender while sentencing him with a suspended execution of the death penalty, focusing on the sentencing. That is, the judge has decided to use lifelong imprisonment for the offender before the suspension of execution of his sentence, and no 
matter how the offender performs in prison, whether he has made significant contributions or whether he has committed intentional crimes within two years of suspension, these are not considerations when the judge declares that lifelong imprisonment is applicable to the offender. This also shows from another aspect that if criminals want to get a lighter punishment, they can only make corresponding acts before making a judgment, so that judges can take these acts into account when making a judgment, thereby mitigating the punishment of criminals.

\subsection{Applicable object of lifelong imprisonment}

According to our understanding and interpretation of the Interpretation of Time Effectiveness, for the application of lifelong imprisonment, there is a major premise, that is, the perpetrator of lifelong imprisonment must be sentenced to death according to law first, the crime is extremely bad, the social influence is extremely serious criminal acts, will be included in lifelong imprisonment. Therefore, the object of lifelong imprisonment can be divided into two kinds: one is that lifelong imprisonment should be applied according to the provisions of the Amendment to the Criminal Law (9); the other is that death penalty should be suspended and commuted to lifelong imprisonment after two years of execution before the promulgation of the Amendment to the Criminal Law (9). Reasonable evaluation of the actor's behavior, cannot be punished as its crime, should also apply to lifelong imprisonment.

\subsection{Applicable Conditions of Lifelong Imprisonment}

Article 383 of the current Criminal Law expressly stipulates that "if the amount is especially huge and the interests of the state and the people suffer heavy losses, they shall be sentenced to lifelong imprisonment or death penalty and confiscation of property". Therefore, when we discuss the applicable amount of lifelong imprisonment, we should have a correct understanding and interpretation of this law. In the above-mentioned articles of law, the circumstances of sentencing to fixed-term imprisonment of more than 10 years or lifelong imprisonment are considered to be particularly serious in other circumstances. Only when the amount specified in the article is met at the same time and the interests of the country and the people are greatly damaged, can the perpetrators of corruption and bribery be sentenced to lifelong imprisonment or the situation of death penalty. As shown in the following table:

Table 1.The amount of embezzlement and bribery in lifelong imprisonment

\begin{tabular}{cc}
\hline case & Amount of bribery \\
\hline Ba Pei case & 246 million yuan \\
Wei Penguin case & 211 million yuan \\
Bu Tie case & 306 million yuan \\
\hline
\end{tabular}

If we want to clearly define the applicable conditions of lifelong imprisonment, we need to make it clear that the perpetrators of lifelong imprisonment must meet the suspension of execution of death penalty. At the same time, because of the huge amount of corruption and bribery of the perpetrators, the country and the people have caused particularly huge losses. At the same time, when the judge hears the case, both of them are satisfied. Only then will the system of lifelong imprisonment be considered.

\section{Summary}

Lifelong imprisonment system is stipulated as a new thing in the amendment of our criminal law. 
Lifelong imprisonment, as a special measure put forward by our country against the serious anti-corruption situation nowadays, regulates and limits the crime of corruption and bribery, which is conducive to the real improvement of our anti-corruption situation, but also to the improvement of our present situation. Some penalty systems effectively remedy the structural defects of the criminal law of our country, which emphasizes death penalty and neglects life penalty, which is a bold attempt under the social background of calling for the abolition of death penalty and paying attention to human rights. It is believed that after a certain period of practice and precipitation, we will define lifelong imprisonment more accurately, formulate more detailed rules of use, make it play its due role and value in judicial practice, improve the severe situation of anti-corruption in our country, alleviate various social contradictions, and realize the harmony and stability of our society.

\section{References}

[1] He Xiang. Application of Death Penalty and Its Value Orientation. [M]. Beijing: People's Public Security University Press, 2008:38.

[2] Mark Chang. Principle of Comparative Criminal Law [M] Wuhan: Wuhan University Press, 2002:849.

[3] Huang Lilongwe. Reform and development of commutation and parole system in China [M]. Beijing: Law Publishing House,2012:22-24.

[4] Chaos Binning. Criminal Law Theories Series [C]. Beijing: Law Publishing House, 2015:15-17.

[5] Chi San'a, Wang Shmo and Li Chan. Interpretation and Application of Amendment (9) to the Criminal Law of the People's Republic of China [M].Beijing: People's Court Press, 2015:24-27. 